\title{
The Role of Technology in Music Education: a Survey of Computer Usage in Teaching Music in Colleges of Education in The Volta Region, Ghana
}

\author{
*Eddison Foster Mawusi, Klutse Eric Kwadwo \\ Mphil. E.P. College of Education, Bimbila. Ghana W/A \\ E. P. College of Education, Bimbila. Ghana, W/A
}

\begin{abstract}
The study sought to find out the role of computer technology in music education in Colleges of Education in the Volta Region of Ghana. It aimed at surveying the use of computer technology for teaching music and exploring the instructional prospects for computer technology usage in music in Colleges of Education. The study employed Rogers' Diffusion Innovation theory and descriptive survey research method. Data was collected from the respondents using questionnaire, interview, and observation. The study revealed that even though about $90 \%$ of the music tutors have good academic qualification and over five years teaching experience, lack of competence in handling computer technology in teaching music among some music tutors and incoherent ICT initiatives hindered proper application of computer technology in the field of music education. It is however envisaged that increasing access and coherent computer technology initiatives will be paramount for the teaching of music in the Colleges of Education.
\end{abstract}

Keywords: Akatsi College of Education, Akatsi (AKATSICO),St. Francis College of Education, Hohoe (FRANCO), St. Teresa's College of Education, Hohoe (TERESCO) ,Jasikan College of Education, Jasikan (JASICO)

Peki College of Education, Peki (GOVCO), E. P. College of Education, Amedzofe (AMECO) and Dambai College of Education, Dambai (DATCO)

\section{Background of the Study}

The application of Information and Communication Technology (ICT) in sectors of human endeavour including education seems to be a paradigm shift from the normal traditional concepts of operations towards a more refined and transformational processes with significant enthusiasm. Social, political, religious, economic, and technological changes of the past decades make education and training for all and sundry more crucial than ever. However, educational systems, to different degrees worldwide, are struggling to afford educational opportunities for all, to provide their human resource with the necessary knowledge and skills for capacity building in evolving economies and sophisticated living environments, and to prepare citizens for lifelong learning (Soloway \& Pryor, 1996). In order to meet these challenges, many Sub-Saharan African countries have to focus concurrently on access enabling environments, improving internal efficiency, promoting the quality of teaching and learning, and improving system management. The application of computer technology in the field of education has gained and rapidly continues gaining ground in various institutions around the globe. With the ever increasing changes in the global economy, Africa for that matter Ghana's educational sector has been challenged to enhance its instructional technology in order to participate effectively in the global technological age (Reeves \& Jonassen, 1996).

Developing nations like Ghana also perceive integration of ICT in education as an engine for promoting socioeconomic, political, and sustainable development. This perception underpins many major attempts to improve upon the educational sector to meet the demand and human resource requirement of the country (Mangesi, 2007). 
The quest for educational improvement as stated by Mangesi triggered the enactments of several educational reforms and initiatives. The Ghana Education Trust Fund (GET Fund Act, 2000) was established to provide educational infrastructure for schools, colleges and universities. The New Educational Reform (2007) incorporated the study of ICT in Basic and Senior High School and establishment of Ghana Investment Fund for Electronic Communication with the vision of bridging the digital divide between the served and unserved/underserved communities in Ghana. According to UNESCO (2008), all over the world, educators, policy makers, policy implementers and researchers have collectively agreed on the potential of ICT to have a significant and positive effect on education (http://en.unesco.org/themes/ict-education).

The Government of Ghana's efforts in recognizing the benefits of embracing ICT and incorporating it in the latest educational reforms which took effect from the 2007/2008 academic year, has been done to enhance the efficiency and effectiveness of the teaching and learning process. It also aimed at equipping the nation's human resource capacity base with the requisite ICT skills and knowledge to meet the challenges of the ever changing world that await them outside the classroom (Ghana ICT in Education Policy, 2015). Education policymakers in Ghana have applauded the introduction of Information and Communication Technology (ICT) in sectors of education as a step towards knowledge production and communication, and information sharing among students and teachers in the school system (Ghana ICT in Education Policy, 2015. pp. 12). As a result of the educational reforms currently underway ICT has been introduced as a subject of study and computer technology as a tool for teaching and learning. This requires a huge capital investment. The Colleges of Education have been entrusted with oversight and implementation responsibility towards insuring effective integration of ICTs and training of teachers for basic school in Ghana.

The major concern here is how much computer technology has been integrated into the teaching of music in the Colleges of Education. How are computer technology used in the teaching of music towards effective music teacher training; these and many more questions not answered propelled the choice of the sector that trains the human resource for our basic schools and a particular area of music education. As a matter of necessity, regarding technology integration in education in Ghana, the question still exists as to what role technology plays in transmission of knowledge and lesson delivery. In an attempt to answer the question, we turn to learn from similar past experiences, improve service delivery in particular, plan and allocate resources to teaching and learning, and finally demonstrate results.

It has been over ten (10) years of introduction of computers and other ICTs in Colleges of Education in Ghana (Ghana ICT for Accelerated Development (ICT4AD) Policy, 2003, pp. 38). The purpose for the integration process was to enhance teaching and learning and to help diffuse new pedagogies across learning experiences in the educational system. Surprisingly, many tutors and students have perceived the use of ICTs as means to an end but not as a tool for teaching, learning and development. Seemingly, for the past eleven years of ICT becoming a subject of study and a tool for teaching and learning, there has not been any research purposively directed to assess the usage of technology in terms of computer in the teaching of music in Colleges of Education in Ghana. Interestingly, the Colleges of Education are responsible for the training of music educators for basic schools. Again, apparently there are scarce or no documents in relation to the use of computer technology in teaching music in the teacher training institutions in Ghana.

Some music tutors in Colleges of Education are enthusiastic about using technological tools like computers in their lesson delivery. The same way some principals are interested in improving teaching of music in their colleges.

The apparent reluctance of older teachers to use technology is understandable to some degree. This might explain why technology, when used by such teachers, is often utilized in a past model of teaching and learning. The question must be asked how open minded and sensitive are college music tutors in terms of computer usage to preparing students for knowledge and skills that can equip them for both the present and the future. The researcher was motivated by the public sector led ICT initiatives in Colleges of education and embarked to survey the use of computer technology in teaching music.

\section{Research Questions}

The following research questions were formulated to guide the study: 
i) What computer technologies are available for music education in colleges of education in the Volta Region?

ii) What is the role of computers in music instruction in colleges of education?

\section{Significance of the Study}

The benefits that computer technologies bring are unhidden fact. This study sought to provide useful lesson for policy makers on the nature of future ICT usage in teaching of Music and to serve as an assessment for the public sector led ICT initiatives to the central government. Again, the study sought to espouse the awareness of the importance of using appropriate computer technology facilities in teaching other subjects and to provide some base knowledge for future research in this area. The researcher thereby hopes that this thesis will provide the basis for anyone who may wish to research into similar work for any educational institution in Ghana and elsewhere.

\section{Theoretical framework of the Study}

This study primarily was based on the theory propounded by Rogers (1962), known as the Theory of Diffusion Innovation. Diffusion Innovation theory is defined as the process by which an innovation is adopted and gains acceptance by members of a certain community. Rogers (2003) stated that adoption is a decision of "full use of an innovation as the best course of action available" and rejection is a decision "not to adopt an innovation" (p. 177). According to Rogers, there are a number of factors that interplay to influence the diffusion of an innovation. These factors include the innovation itself, how information about the innovation is communicated (communication channel), time, and the nature of the social system (the institution) into which the innovation is being introduced (Rogers, 1962). In view with Rogers, the introduction of new technology must be well explained to users and considering the appropriateness of the technology to the sector that is to use it. The medium of communication becomes paramount for the user institution. The question that remains answered is how much education was done before and during the computer integration in colleges of education in Ghana. How much awareness of computer literacy was created in both students and tutors of colleges of education? In any case, Rogers' assertion is right because it calls for proper assessment and analysis of colleges of education's computer technology needs for effective use of computer technology in education.

\section{a) Innovation:}

According to Rogers (2003), innovation is an idea, practice, or object that is perceived as new by an individuals or groups or unit of adoption. The perception of an innovation and the rate of adoption are usually determined by the members of the social system based on certain characteristics such as: relative advantage, compatibility, complexity, trialability and observability. Here, Rogers are of the view that the acceptance of any innovation for that matter computer technology into any social setting must be well weighed. The said innovation must be simple to operate, suitable to the environment or the social setting, user friendly and appealing. Again, a critical consideration must be given to the advantage the innovation has over the existing one in use. It is therefore believed that computer technology would play roles that are more cost efficient in the delivery of music lessons over the traditional set standards.

\section{b) Communication:}

Communication is the process by which participants create and share information with one another in order to reach a mutual understanding (Rogers, 2003). A communication channel according to Rogers is the means by which messages get from one individual to another. Rogers states "source is an individual or an institution that originates a message, a channel is the means by which a message gets from the source to the receiver" (p. 204). Mass media channels are more effective in creating knowledge of innovations, whereas interpersonal channels are more effective in forming and changing attitudes toward a new idea, and thus in influencing the decision to adopt or reject a new idea. Rogers stated "diffusion is a very social process that involves interpersonal communication relationships" (Rogers, 2003, p. 19). Most individuals evaluate an innovation, not on the basis of scientific research by experts, but through the subjective evaluations of nearpeers who have adopted the innovation. Rightly said, easy adoption of any technology means practical hands-on by an individual. Better learning experience takes place among peers. For new technology to be well adopted in an institution, individual must have adequate access and frequent interpersonal relationship with the technology and other peers that use the same technology.

c) Time 
Rogers believed that in diffusion of innovation, time involves three things.

i) The innovation-decision process. This is the mental process through which an individual (or other decision making unit) passes from first knowledge of an innovation to forming an attitude toward the innovation, to a decision to adopt or reject, to implementation of the new idea, and to confirmation of this decision. An individual seeks information at various stages in the innovation-decision process in order to decrease uncertainty about an innovation's expected consequences. There are five steps involved namely: 1) Knowledge, 2) Persuasion, 3) Decision, Confirmation.

ii) The innovativeness of an individual or other unit of adoption. This involves the degree to which an individual or other unit of adoption is relatively earlier in adopting new ideas than other members of a social system. There are five adopter categories, or classifications of the members of a social system on the basis on their innovativeness: 1) Innovators, 2) Early adopters, 3) Early majority, 4) Late majority and 5) Laggards.

According to Malachi (2007) in his unpublished thesis, stated that the Innovators are those who are interested in technology itself, financially sound, well-educated and risk undertakers. Early adopters may be technically sophisticated and interested in technology for solving professional and academic problems. Early majority are pragmatists and constitute the first part of the mainstream; Late Majority are less comfortable with technology and are the skeptical second half of the mainstream; laggards may never adopt technology and may be antagonistic and critical of its use by others. They are financially less stable, conservative, less educated and fear to undertake risky operations.

iii) The rate of adoption. This is the relative speed with which an innovation is adopted by members of a social system. The rate of adoption is usually measured as the number of members of the system that adopt the innovation in a given time period.

d) Social System

Rogers (2003) defined social system as "a set of interrelated units engaged in joint problem solving to accomplish a common goal" (p. 23). Since diffusion of innovations takes place in the social system, it is greatly influenced by the social structure of the social system such as norms, opinion leaders, and the degree to which an individual is able to informally influence other individuals' attitudes or overt behavior in a desired way with relative frequency. The members or units of a social system may be individuals, informal groups, organizations, and/or subsystems. The social system constitutes a boundary within which an innovation diffuses and a change agent is an individual who attempts to influence clients' innovationdecisions in a direction that is deemed desirable by a change agency.

This diffusion innovations theory by Rogers, all over the years, is believed to be the most appropriate for investigating the adoption of technology in higher education and educational environments (Medlin, 2001; Parisot, 1995); hence appropriate for this study. This theory was viewed appropriate for the study as it laid a strong case for the adoption of computer technology as a new educational tool and its usage in music education. Technology integration in education in Ghana is quite new process. In Ghana, the policy document for National ICT Programme seeks to inform sector stakeholders as to why ICTs are very important part of our modern society. Again, it looks at the eminent roles teaching of music play in our educational system and life as general for which much attention must be given. Learning is said to be mediated by tools and signs. These tools are said to be created by the culture of the people in which the environment places greater role. Computer technology as a tool changes the culture. The purpose of the tool is to meet the goals of the participants in the culture and thereby transforming their participation in the culture (Duffy \& Cunningham, 1996).

There are indications that teachers proceed to adopt ICTs in stages and initially focus on their own interaction with the new medium, and as they gradually become comfortable with the technology they start deliberating upon potential learning benefits that would result from the use of the computer. Myhre (1998) concludes that this increased familiarity with computers allows teachers to turn their interest to the pedagogical use of technology rather than its operational issues, but also emphasizes that such change processes do not occur rapidly and are not easily achieved. Tutors and students and even policy makers struggle to comprehend working dynamics of this innovation. Many old folks in the educational system reject computers and their capabilities while the young appreciate the device. The world today is viewed as a global village. Ghana as a country benefited from the influx of knowledge about the eminent roles played by 
technology for that matter computer technology. There is therefore the need to assess how far this new tool (innovation) has been adopted and used within the context of music teaching. It is in this regard that Surry (1997) asserted that increased awareness of diffusion's importance and expanded use of diffusion theories are of potentially great benefit to instructional technology in the field of music education.

\section{Research Design}

The research was conducted using the Descriptive Survey design. According to Marilyn Zurmuehlin Working Papers in Art Education1 (1981), a descriptive survey is a research design that attempts to establish the range and distribution of some social characteristics, such as education or training, occupation, and location, and to discover how these characteristics may be related to certain behavior patterns or attitudes. The design was found suitable since such a research describes and predicts phenomena without manipulating factors that influence the phenomena (Amedahe, 2002). The ultimate goal of this research was to find out the usage of computer technology in the teaching of music in colleges of Education in Ghana in the Volta Region, explain the present computer technology usage in music education as well as to outline the prospects of computer technology application in music education. In addition, the study was envisaged to make a change in the way and direction public sector led ICT initiatives for colleges and school are undertaken.

Razavieh (1990) came out that descriptive research studies are designed to obtain information concerning the current state of affairs. Such a study is undertaken in order to ascertain and be able to describe the characteristics of the variables of interest in a situation. Its purpose is to learn about a large population by surveying a sample of that population; describe, clarify and interpret aspects of education as they presently exist. A descriptive survey design was chosen because of the economy of the design, the rapid turnaround time in data collection (Creswell, 2003) and the ease of data interpretation by the use of simple descriptive statistics. Again Creswell was with the view that choosing descriptive survey design allows for more confidentiality with those being surveyed and furthermore provides a meaningful picture of events and seeks to explain people's perceptions and behaviour on the bases of the data collected.

According to Schwarz (1999), despite the successes of using this design for the research, difficulties associated with such a design needs to be addressed. One problem is that some people may intentionally misrepresent the facts in order to present a favourable impression to the researcher. Sometimes inability of respondents to articulate their thoughts clearly and poor research instruments could be factors that affect the research outcome. Nonetheless, this is addressed in view of using a variety of instruments such as face-toface interviews, telephone interviews and written questionnaire to collect data from a variety of sources.

\section{Sources of Data}

The research made use of two sources of data namely primary source and secondary source. The primary source of data for the research was the data obtained from the participants through questionnaire, interview and observation made by the researcher. The secondary source of data were taken from reports of studies done on computer technology in education, especially with regards to teaching of music in Colleges of Education in Ghana and elsewhere, information from the internet as well as other relevant studies on the activities under study, preliminary studies done by the Information and Communication Technologies in Education Programmes Unit (ICTEPU) of the Ministry of Education Science and Sports (MOESS) on ICT initiatives in Ghanaian Schools (National ICT4AD policy, 2004).

\section{Population}

The survey was conducted in seven (7) Public Colleges of Education in the Volta Region of Ghana. The study involved music tutors, elective music students and level 200 students who studied music in the first year first semester. The seven Public Colleges of Education that were used in study were: Table 1 


\begin{tabular}{|l|c|c|c|c|c|c|}
\hline College & $\begin{array}{c}\text { Total No. } \\
\text { of students }\end{array}$ & $\begin{array}{c}\text { No of } \\
\text { students } \\
\text { Sampled } \\
(\mathbf{n = 1 4 0})\end{array}$ & $\begin{array}{c}\text { No. of Level } \\
\mathbf{2 0 0} \text { students }\end{array}$ & $\mathbf{\%}$ & $\begin{array}{c}\text { No. Elective } \\
\text { Students }\end{array}$ & $(\boldsymbol{\%})$ \\
\hline GOVCO & 150 & 20 & 8 & $40.0 \%$ & 12 & $60.0 \%$ \\
\hline AKATSICO & 175 & 20 & 20 & $100.0 \%$ & 0 & $0.0 \%$ \\
\hline AMECO & 150 & 20 & 20 & $100.0 \%$ & 0 & $0.0 \%$ \\
\hline TERESCO & 150 & 20 & 20 & $100.0 \%$ & 0 & $0.0 \%$ \\
\hline FRANCO & 160 & 20 & 0 & $0.0 \%$ & 20 & $100.0 \%$ \\
\hline DATCO & 130 & 20 & 20 & $100.0 \%$ & 0 & $0.0 \%$ \\
\hline JASICO & 150 & 20 & 20 & $100.0 \%$ & 0 & $0.0 \%$ \\
\hline Total & $\mathbf{1 0 6 5}$ & $\mathbf{1 4 0}$ & $\mathbf{1 0 8}$ & $\mathbf{7 7 . 1 \%}$ & $\mathbf{3 2}$ & $\mathbf{2 2 . 9 \%}$ \\
\hline
\end{tabular}

\section{Source: Field study, 2019}

\section{Sample and Sampling Techniques}

A combination of sampling techniques was used for the research. Purposive sampling was used to select the seven (7) Colleges of Education for the study. This was done by selecting all the seven public colleges in the Volta Region. The same sampling technique was used to select the 32 level two hundred (200) elective music students and seven (7) music tutors from the seven (7) selected colleges. The purposive sampling technique was chosen for the study because the subjects selected satisfied certain qualities which are not randomly distributed but they exhibit most of the characteristics of interest to the study (Amedahe, 2000). It must be noted however that the choice of the Colleges of Education and the music education were based on prior knowledge of the researcher as one of the music tutors teaching in Peki College of Education. Simple Random Sampling Technique was used to select the twenty (20) level two hundred (200) students who studied music in the first year from each college. Two (2) students were randomly selected from each class in each college and based on gender i.e. one male trainee and one female trainee. This was done by paper folding method that indicated "YES" or "NO" options. Simple random sampling technique gave all units of this target population an equal chance of being selected. It is said to be very reliable, with high degree of representativeness and generalization of research results (Amedahe, 2000).

Research Instruments: The main instruments that were employed to obtain data for the study were: questionnaire, interview and observation.

\section{Questionnaire}

In this study, the questionnaire sought to collect background information of the respondents. It included both close-ended and open-ended items. There were two categories of questionnaire administered; questionnaire for the music tutor and questionnaire for the music students. The questionnaire also covered issues very pertinent to the unraveling of the research problem. The music tutor's questionnaire was focused on the background information on the availability of computer technology facilities in the colleges, professional qualification of music tutors, teaching experiences, tutor competence in the use computer technology and attitudes towards the use of computer technology in music education. The questionnaire for the music students on the other hand sought to generate responses that validate the information given by the music tutors. It touched on issues of technological resources available for learning music and accessibility of the facilities to the music students. The researcher chose questionnaire because it allowed respondents to express their views about a particular topic since some of its items were open ended. It also saved the researcher's time and lengthy explanations of item since the respondents responded to the items independently. The anonymity (nature of confidentiality) of questionnaire was also considered a relevant issue which made it a preferred option. The general benefits of a questionnaire which the researcher thought 
to make it appropriate were: consistency of presentation of questions to the respondents, a greater perception of anonymity for the respondents and less time consuming to administer.

\section{Interview}

The purpose of an interview was to find out what precise ideas the participants held on the use of computer technology in music education. To obtain additional data for the study, a semi-structured interview guide was prepared. This was done to seek information from individuals such as Assessment officers of the colleges selected, students and tutors other than selected participants and people whose views were very much of help to the cause of this research and were connected with activities of the institutions under study. The researcher employed oral interview to seek more information about the physical presence and the use of computer technology tools in the classroom. This was done to enable the researcher get more first-hand information that have not been covered by the questionnaire and could best be explained orally than writing. In all, twenty (20) participants were interviewed.

\section{Observation}

The observation was prepared to identify issues, activities and other happening of interest, as far as the study is concerned, which fed into the questionnaire and interviews. The researcher intended to use observation for two reasons:

i) Ascertain the fact about the physical presence and availability of computer technology in the selected colleges as recorded in the questionnaire and interview.

ii) To gather data on practical teaching of music lessons and how computer technology was used during lesson delivery as well as practical application of computer technology and other musical technologies in students' campus life.

\section{Data Collection Process}

The researcher took eight (8) weeks to collect data for the study. In the first week, preliminary contacts were made with the Heads of Departments and Music tutors of seven (7) selected public Colleges of Education in the Volta Region. Due to the vastness of study area, this early contacts were made through telephone calls. The purpose and significance of the research was discussed with them and permission as well as their support sought for the exercise. Specific times to carry out the exercise in selected colleges were fixed. Initially, the researcher intended to use two weeks for the administration and collection of completed questionnaire but it turned to cover four weeks. The questionnaire was administered in the second week to the students and music tutors of the selected colleges. Only three colleges were able to meet the deadline of two weeks of administration and collection of completed questionnaire while the rest four presented the completed questionnaire within the sixth week. The collection of the completed questionnaires from each college was done by courtesy of a volunteer on behalf of the researcher. The researcher in the midst of the apparent delay in completion of the questionnaire, gave the respondents enough time to respond to the questionnaire so that they were not forced to respond to it 'under pressure' and secondly to ensure anonymity of respondents and hopefully elicited more genuine response from them.

The interview sessions with selected respondents took four weeks. Fourteen (14) selected interviewees were contacted in the third week of the data collection process. Eight (8) of the interviewees consisting five (5) Assessment officers and three (3) Heads of Departments were contacted through telephone calls while six (6) others made up of five Heads of Departments and three Assessment officers were met face to face by the researcher. The purpose and significance of the research was discussed and specific times to carry out the interviews fixed. The researcher interviewed people on individual bases and also groups such as class of students (seven classes that were observed). During the interview, responses were recorded manually and also with the help of a mini digital recorder and call record system of a mobile phone. The last interview was carried out in the eighth week. The results of the interview were used to confirm the responses of music tutors and students on the questionnaire.

The researcher used the observation to solicit verification of physical presence of computer technology in the seven participating colleges. The observations were done during music lessons. In each of the seven colleges, the researcher observed one music lesson. The following were observed: 
a) Type of computer technology available during lesson delivery

b) The use of available computer technology in lesson delivery and

c) Students' response during lesson delivery.

The observations began alongside the interview during the fourth week. It became necessary to combine the two instruments at the same time due to the high cost element of travelling from college to college. The researcher arrived early enough to observe the classroom environment and also tested some of the equipment before lectures. The observation guide was used (see Appendix C, pp. 117). The data collected through the observations were compared with the responses provided on the questionnaire and were used to confirm the research findings and provision of appropriate recommendations.

\section{Data Analysis}

The researcher employed descriptive statistical methods to analyze the data. The data obtained were edited, coded and entered into a computer and organized around a number of research questions raised in Chapter 1 using tables. The information collected was tabulated in frequency tables and expressed in percentages for the quantitative data interpretation and discussion. The tables brought out the true picture and quick visual impression of the research results. Recorded interviews were transcribed, and together with textual data from interviews were analyzed and discussed to corroborate the data obtained from the questionnaire. The observation data collected were also analyzed in line with the questionnaire for confirmation of availability of computer technology and its use and finally discussed under the related themes.

\section{Tutor teaching experience and professional qualification}

Table below shows the responses in terms of the state of the tutors' teaching experiences and their professional qualifications. Table 2

Source: Field study, 2019

\begin{tabular}{|l|c|c|c|c|c|c|c|}
\hline College & $\begin{array}{l}\text { M.Phil. (Music } \\
\text { Education) }\end{array}$ & $\begin{array}{c}\text { M.A } \\
\text { (Music) }\end{array}$ & $\begin{array}{c}\text { M.ED } \\
\text { (Music) }\end{array}$ & $\begin{array}{c}\text { B.ED/BA } \\
\text { (Music) }\end{array}$ & $\begin{array}{c}\text { Diploma } \\
\text { (Music) }\end{array}$ & $\begin{array}{c}\text { Certificate } \\
\text { (Music) }\end{array}$ & Total \\
\hline 0-2 years & 0 & 0 & 0 & 0 & 0 & 0 & $\mathbf{0}$ \\
\hline 3-4 years & 0 & 0 & 0 & 1 & 0 & 0 & $\mathbf{1}$ \\
\hline 5-9 years & 0 & 0 & 2 & 0 & 0 & 0 & $\mathbf{2}$ \\
\hline $\begin{array}{l}\text { Over 10 } \\
\text { years }\end{array}$ & 4 & 0 & 0 & 0 & 0 & 0 & $\mathbf{4}$ \\
\hline Total & $\mathbf{4}$ & $\mathbf{0}$ & $\mathbf{2}$ & $\mathbf{1}$ & $\mathbf{0}$ & $\mathbf{0}$ & $\mathbf{7}$ \\
\hline
\end{tabular}

Table below shows the responses in terms of the state of the tutors' teaching experiences and their professional qualifications.

Table 3: Tutor teaching experience and professional Qualification

\begin{tabular}{|l|c|c|c|c|c|c|c|}
\hline College & $\begin{array}{l}\text { M.Phil. (Music } \\
\text { Education) }\end{array}$ & $\begin{array}{c}\text { M.A } \\
\text { (Music) }\end{array}$ & $\begin{array}{c}\text { M.ED } \\
\text { (Music) }\end{array}$ & $\begin{array}{c}\text { B.ED/BA } \\
\text { (Music) }\end{array}$ & $\begin{array}{c}\text { Diploma } \\
\text { (Music) }\end{array}$ & $\begin{array}{c}\text { Certificate } \\
\text { (Music) }\end{array}$ & Total \\
\hline 0-2 years & 0 & 0 & 0 & 0 & 0 & 0 & $\mathbf{0}$ \\
\hline 3-4 years & 0 & 0 & 0 & 1 & 0 & 0 & $\mathbf{1}$ \\
\hline 5-9 years & 0 & 0 & 2 & 0 & 0 & 0 & $\mathbf{2}$ \\
\hline $\begin{array}{l}\text { Over 10 } \\
\text { years }\end{array}$ & 4 & 0 & 0 & 0 & 0 & 0 & $\mathbf{4}$ \\
\hline Total & $\mathbf{4}$ & $\mathbf{0}$ & $\mathbf{2}$ & $\mathbf{1}$ & $\mathbf{0}$ & $\mathbf{0}$ & $\mathbf{7}$ \\
\hline
\end{tabular}

\section{Source: Field study, 2019}

Table 3 indicates the teaching experience and professional qualification of music tutors. According to the table, four (4) tutors (54.1\%) had over 10 years teaching experience with M.Phil. (Music Education) degree qualification, seven (2) tutors (28.6\%) had 5-9 years teaching experience with M.ED (Music) degree qualification and 1 tutor (14.3\%) had 3-4 years' experience in teaching with B.ED (Music) degree qualification. In line with the status and the harmonized scheme of the Colleges of Education in Ghana, the minimum qualification for a tutor is masters' degree. The findings of the table revealed that out of the seven (7) tutors who responded, six (6) representing $85.7 \%$ are duly qualified and one (1) representing $12.5 \%$ has not met the requirement. This implies that almost $90 \%$ of the sampled colleges have no challenges in terms 
of tutor qualification. In terms of tutor's teaching experience, majority of the tutors had gained teaching experience over seven (7) years which places colleges of education in a comfortable position for effective delivery.

Table 4: Students' response regarding availability of technological facilities and their usage

\begin{tabular}{|c|c|c|c|c|}
\hline \multirow{2}{*}{$\begin{array}{l}\text { Type of } \\
\text { Technology }\end{array}$} & \multicolumn{2}{|c|}{$\begin{array}{l}\text { Availability of Technology } \\
\text { in Colleges }\end{array}$} & \multicolumn{2}{|c|}{ Usage } \\
\hline & $\begin{array}{c}\text { No. of colleges } \\
\text { with tech. } \\
(n=7)\end{array}$ & $\%$ & $\begin{array}{c}\text { No. of Colleges } \\
\text { Using tech. }(n=7)\end{array}$ & $\%$ \\
\hline Computer & 7 & $100 \%$ & 1 & $14.3 \%$ \\
\hline $\begin{array}{l}\text { Electronic } \\
\text { Keyboard }\end{array}$ & 6 & $85.7 \%$ & 5 & $71.4 \%$ \\
\hline $\begin{array}{l}\text { Musical Digital } \\
\text { Recorder }\end{array}$ & 2 & $28.6 \%$ & 1 & $14.3 \%$ \\
\hline $\begin{array}{l}\text { Others (drums, } \\
\text { radio, CDs, } \\
\text { flutes etc.) }\end{array}$ & 4 & $57.1 \%$ & 3 & $42.9 \%$ \\
\hline
\end{tabular}

\section{Source: Field Study, 2019}

Table 4 illustrates students' responses regarding availability of technological facilities and their usage in music education in their colleges. Seven (7) colleges responded positive to availability of computers representing 100\%, 6 colleges representing $85.7 \%$ confirmed having electronic keyboards, only two (2) colleges with $28.6 \%$ had Musical Digital Recorders and four (4) colleges agreed having other technologies (drums, CDs, etc) representing 57.1\%. As indicated by the table above, out of seven (7) colleges with computers, one (1) college (14.3\%) only agreed using computers in teaching music, five (5) colleges $(71.4 \%)$ agreed using electronic keyboard during music lessons, one (1) college representing $14.3 \%$ agreed using Musical Digital Recorders and three (3) colleges representing 42.9\% agreed to have being using other technologies (drums, CDs, etc.) for music education.

Table 5: Music teachers' response regarding music technology equipment available in colleges and their usage

\begin{tabular}{|c|c|c|c|c|}
\hline \multirow{2}{*}{$\begin{array}{l}\text { Type of } \\
\text { Technology }\end{array}$} & \multicolumn{2}{|c|}{$\begin{array}{l}\text { Availability of Technology in } \\
\text { Colleges }\end{array}$} & \multicolumn{2}{|l|}{ Usage } \\
\hline & $\begin{array}{l}\text { No. of colleges with } \\
\text { tech. }(n=7)\end{array}$ & $\%$ & $\begin{array}{l}\text { No. of Colleges Using } \\
\text { tech. }(n=7)\end{array}$ & $\%$ \\
\hline Computer & 7 & $100 \%$ & 7 & $100 \%$ \\
\hline Electronic Keyboard & 6 & $85.7 \%$ & 5 & $71.4 \%$ \\
\hline Music Software & 7 & $100 \%$ & 7 & $100 \%$ \\
\hline Musical Digital Recorder & 1 & $14.3 \%$ & 1 & $14.3 \%$ \\
\hline $\begin{array}{l}\text { Others (drums, radio, } \\
\text { CDs, flutes etc.) }\end{array}$ & 3 & $57.1 \%$ & 3 & $42.9 \%$ \\
\hline
\end{tabular}

\section{Source: Field study, 2019}

Table 5 shows Music Tutors' responses regarding availability of technological facilities and their usage in music education in their colleges. Seven (7) music tutors agreed having computer in their colleges representing $100 \%$, contrary to students' response of six (6) colleges $(85.7 \%)$ with electronic keyboards, 
seven (7) music tutors responded positively representing 100\%. Again, while students of two (2) colleges (28.6\%) only confirmed having Musical Digital Recorder, only one (1) tutor (14.3\%) agreed to have Musical Digital Recorder in college. Seven (7) music tutors (100\%) indicated that their colleges had music software and only three (3) music tutors confirmed having other technologies. In the case of technology usage, seven (7) music tutors agreed to have been using computers, five (5) tutors agreed using electronic keyboard (71.4\%) and seven (7) confirmed using music software representing $100 \%$ each, only one (1) music tutor confirmed using Musical Digital Recorder and three (3) tutors indicated that they use other technologies in their colleges.

\section{The role of computers in music instruction in colleges of education}

This section shows responses of students and tutors regarding the role of computer technology in music instruction in seven (7) public colleges of education in the Volta Region. Areas covered were: Music tutors' response on their formal training as music educators to handle music technology, Students' response on curriculum areas supported through the use of music technology, Music tutors' response to types of technology and the curriculum areas supported through the use of technology, and Music tutors' response regarding the Basic /simple use of applications for the purposes of Music Education.

Table 6: Music tutors' response on their formal training as music educators to handle music technology

\begin{tabular}{|l|c|c|c|c|}
\hline & \multicolumn{2}{|c|}{$\begin{array}{l}\text { No. of Tutors } \\
\text { trained to handle } \\
\text { music technology }\end{array}$} & \multicolumn{2}{c|}{$\begin{array}{c}\text { Tutors Not-trained to } \\
\text { handle music technology }\end{array}$} \\
\hline & $(\mathbf{n}=\mathbf{7})$ & $\%$ & $(\mathbf{n}=\mathbf{7})$ & $\%$ \\
\hline Computer & 3 & $42.9 \%$ & 4 & $57.1 \%$ \\
\hline Electronic Keyboard & 7 & $100 \%$ & 0 & $0 \%$ \\
\hline Music Software & 3 & $42.9 \%$ & 4 & $57.1 \%$ \\
\hline $\begin{array}{l}\text { Musical Digital Recorders } \\
\text { Mthers e.g. drums, radio, flute, }\end{array}$ & 0 & 0 & 0 & $0.0 \%$ \\
\hline CDs, etc. & 0 & 0 & 0 & $0.0 \%$ \\
\hline
\end{tabular}

\section{Source: Field Study, 2019}

Table 6 shows music tutors' response regarding their formal training as music educators to handle music technology. According to the table, three (3) music tutors representing $42.9 \%$ had formal training to handle computer while 4 representing 57.1 had no formal training. Seven (7) music tutors had formal training in electronic keyboard representing 100\%. Three (3) music tutors representing $42.9 \%$ had formal training in Music software while four (4) had no formal training. No music tutor had formal training in Musical Digital Recording and others as indicated by the table.

Table 7: Students' response on curriculum areas supported through the use of music technology.

\begin{tabular}{|l|c|c|}
\hline $\begin{array}{l}\text { Music Curriculum areas supported through music } \\
\text { technology. }\end{array}$ & $\begin{array}{c}\text { Students } \\
\text { Frequency }\end{array}$ & $\begin{array}{c}\text { Percentage } \\
\text { (n=140) }\end{array}$ \\
\hline Theory of Music (elements of music) & 15 & $10.7 \%$ \\
\hline
\end{tabular}




\begin{tabular}{|l|c|c|}
\hline Composition (Melody and part writing, skills training) & 22 & $15.7 \%$ \\
\hline History of Music (Western and Contemporary Ghana) & 9 & $6.4 \%$ \\
\hline $\begin{array}{l}\text { Practicals (Voice training, Piano playing part singing, sight } \\
\text { singing, Aurals) }\end{array}$ & 46 & $32.9 \%$ \\
\hline None & 48 & $34.3 \%$ \\
\hline Total & 140 & $100 \%$ \\
\hline
\end{tabular}

Source: Field study, 2019

Table 7 displays students' responses on curriculum areas supported through the use of music technology. Out of 140 students sampled, fifteen (15) students representing 10.7\% agreed that music technology supports the teaching of music theory, twenty-two (22) students representing $15.7 \%$ attested to music technology support for composition, only nine (9) students (6.4\%) agreed that music technology supports the teaching of History of Music. Forty-six (46) students also agreed that Practical are conducted using music technology representing 32.9\% and forty-eight (48) students representing the largest percentage of $34.3 \%$ confirmed that music technology was completely absent from all curriculum areas in their music lessons.

Table 8: Music tutors' response to types of technology and the curriculum areas supported through the use of technology

\begin{tabular}{|l|l|c|c|}
\hline $\begin{array}{l}\text { Music } \\
\text { Technology } \\
\text { available }\end{array}$ & $\begin{array}{l}\text { Music Curriculum areas supported } \\
\text { through music technology }\end{array}$ & $\begin{array}{l}\text { No. of colleges } \\
\text { N=7 }\end{array}$ & \% \\
\hline Computer & $\begin{array}{l}\text { Composition, piano skills, lesson } \\
\text { presentation, CBT, WBT. }\end{array}$ & 7 & $100 \%$ \\
\hline $\begin{array}{l}\text { Electronic } \\
\text { keyboard }\end{array}$ & $\begin{array}{l}\text { Theory ; scales, melody writing playback, } \\
\text { Chord progressions, cadences }\end{array}$ & 7 & $14.3 \%$ \\
\hline $\begin{array}{l}\text { Musical Digital } \\
\text { Recorder }\end{array}$ & $\begin{array}{l}\text { Aurals, Sight singing, scales, melody } \\
\text { writing }\end{array}$ & 1 & $14.3 \%$ \\
\hline $\begin{array}{l}\text { Others i.e. drums, CDs, } \\
\text { flutes etc. }\end{array}$ & Rhythm practice, pitch etc. & 1 & \\
\hline
\end{tabular}

\section{Source: Field Study, 2019}

Table 8 shows music tutors' response to types of technology and the curriculum areas supported through the use of technology. Seven (7) music tutors representing $100 \%$ agreed that computer is used in composition, piano skills, lesson presentation, CBT and WBT, again, seven (7) tutors (100\%) agreed using electronic keyboard in music theory; scales, melody writing, playback, chord progressions and cadences. Only one (1) tutor agreed using Musical Digital Recorder for aural and sight singing. One (1) tutor (14.3\%) also confirmed using other technologies in teaching rhythm practice, pitch, etc. representing $14.3 \%$.

\section{Summary of Findings \\ Computer technology for teaching music in colleges of education}

Evidence from the study indicated that all the selected colleges of education have adequate available and accessible computers. Many of these accessible computers are not distributed across departments (Social Sciences, Mathematics, Science, etc.) but concentrated at college computer laboratories. Computer 
technologies such as electronic keyboard, musical digital recorders and others (drums, CDs, flutes, etc.) that were not directly supplied through public sector ICT initiatives were readily not available to all colleges. In addition, interviews carried out collaborated with the observation process also confirmed that most college administrations denied music departments' full support in acquiring necessary music technology facilities such as electronic keyboard, musical digital recorders and software that augment teaching of music. The cause of this mishap was identified as lack of co-operation, which could be multifaceted and varied among individual administrators and colleges.

\section{The role of computer technology in music instruction}

In terms of tutor qualification and experience, $90 \%$ of tutors from the selected colleges met the required qualification and teaching experience of over five (5) years. This in effect places colleges of education in a comfortable position for effective delivery of music instruction. However, lack of competence to handle music technology facilities such as the computer as revealed in the study, poses a great danger to the future of effective and competitive music education in colleges of education in Ghana. It became evident in the study that the physical presence or availability of computer technology in the colleges selected does not mean that they are always used for the purposes of educational instructions for that matter teaching of music. In each of the selected colleges, the study confirmed the availability of at least one or more music technology types; however, their application in the field of music teaching is imprecise.

\section{Students' usage of computer technology in music education}

The study exposed the fact that apart from the purposes of communication as everyday routine, music students' frequent use of computer technology facilities falls below average. This presupposes students' lack of interest in the use of technology facilities in and outside the classroom, lack of the awareness of the roles of computer technology in music education and lack of competent computer technological skills necessary for music instruction and learning or education. In this regard, careful analysis of the results of the study revealed that tutors resorted to using traditional methods of educational instructions rather than the modern and more appropriate and technologically convenience means. This practice becomes one of the factors eliciting lack of motivation for students who fail to choose music as an elective subject. In other words it should be recorded that lack of students' motivation for the subject music comes as a result of three factors namely: lack of tutor motivation, abstract delivery of music lessons by music tutors and students perception of the subject music as difficult.

\section{Conclusion}

The availability of accessible computers in the colleges of education is a good indicator for embracing technologically enhanced environment for teaching music. Nevertheless, this perception cannot single-handedly make easy the implementation advocacy for the usage of computer technology in music education if colleges lack other technological facilities such as electronic keyboards, musical digital recorders and music software for teaching.

In acknowledging the significant role played by computer technology in music instruction, the consideration for music tutors' competence in colleges of education must go beyond the acceptance of only academic qualifications. However, the process of selecting a college music tutor needs a critical analysis of the potential tutor's competency in handling computer and other music technologies in the classroom. Contrary to this, there is a tendency of varied individual tutor's awareness on the importance and use of computer and music technology facilities thereby defeating the full realization of the significant roles played by computer technology in music instruction.

One important factor that aids diffusion innovation process is motivation. The purpose of the deployment of computer technology to colleges of education cannot be achieved if they are not effectively used by students. From the study, it is concluded that there are two main factors that contribute to student's failure to use computer technology which the researcher referred to as inter and extra factors. The inter factor indicates the satisfaction individual student derives from appreciating the technology (being aware of its capabilities and flexibility) at his or her first encounter that leads to repeated action. The second factor, 
extra, leads to motivation derived by a student as a result of display of competence from a mate or a tutor. In many cases, the tutor being the center of focus provides the motivation during the delivery of lesson through the use of computer technology. These two factors are inseparable of each other. Where one of these factors is downplayed, it results in a learning difficulty referred to by the researcher as technology practice difficulty. This is evident in computer technology that is not user-friendly and abstract lesson delivery lacking the use of computer technology.

Finally, the prospect of computer technology use in music education is paramount. In enhancing effective computer technology music education for colleges of education in Ghana in the $21^{\text {st }}$ Century, Computer Assisted Instructions are indispensable. It is impossible to achieve the full potential of the use of computer technology in music education without integrating computer music technology in the course of study for colleges. Rogers (1962), defines the Theory of Diffusion Innovation as the process by which an innovation is adopted and gains acceptance by members of a certain community. According to Rogers (2003), he states "full use of an innovation as the best course of action available" and rejection is a decision "not to adopt an innovation" (p. 177). In his assertion, it was indicated that innovation itself, how information about the innovation is communicated (channel of communication), time and nature of social system (the institution) into which the innovation is being introduced are factors that interplay to influence the diffusion of an innovation.

The current study in line with its findings agreed with Rogers that lack of competence in the part of the college music tutors to use computer technology in teaching music was greatly influence by the process of imitative integration; the time these initiatives were introduced to colleges and how effective the knowledge of these technologies were communicated to both tutors and students. Lack of interest as shown by the in the part of tutors makes it very difficult for the full adoption of computer technology in teaching music. The introduction of computer technology to colleges of education must be well explained to users (tutors and students) and considering the appropriateness of the technology to the sector (music education) that is to use it. The Diffusion Innovation theory rightly complement to this study to call for proper assessment and analysis of colleges of education's computer technology needs for effective use of computer technology in teaching music.

\section{Recommendations}

From the findings of the study, it is obvious that the Colleges of Education cannot make a head way in the modern trends of music education delivery if certain measures are not taken.

To make the implementation advocacy easy for the usage of technology in music education, there is the need for assessment, focus and redirection of priorities. It is long overdue for public sector to assess and identify the strengths and weakness of all ICT initiatives for colleges of education for further improvement. From the study, the public sector led ICT initiatives were not purposive to the direct needs of different subject orientations; instead individual tutors must be innovative enough in applying them to their fields of endeavour. It is therefore recommended that government's technology initiatives for Colleges of Education be re-designed to provide necessary subject oriented computer hardware and software, and where necessary, as alternative, give right atmosphere to colleges to acquire these facilities at cheaper prices to augment the shortfall in government's subventions. This would help achieve a uniform distribution of computer technologies across colleges. Subsequent initiatives must be concerned with the specific goals of the colleges, subject focus alongside the training requirements for teacher trainees.

In the study, it is revealed that for the success of computer technology in the music education, there must be interest development. Individual tutors and students as well have to whip up interest in availing themselves and making every effort to see technology as an effective tool for service delivery.

In order to supplement and cater for the current backlog of knowledge needed for music education, as revealed by the study, music tutors in the college system should be taken through adequate seminars in the form of workshops, job-related refresher trainings in the knowledge of skills related to application of newly developed technologies in music education. It is hoped that if tutors would use appropriate approaches and principles and achieve the best of accepted standards, students would be motivated to apply same for better 
results. Organizations whose goals are to promote music education such as Association of Music Educators of Colleges of Education in Ghana should be encouraged and supported, as such fora give tutors opportunity for developing and sharing resources, besides providing professional experience. Tutors should develop habit of creating technology environment for student to have frequent hands on practices.

The study showed that the training of music tutors must be subjected to critical assessment. As we think about refresher training for those tutors on the job, the formal training of music tutors should involve taking pre-requisite courses in Information and Communication Technology as a preparatory lesson for effective integration of technology and specifically technology oriented music education courses; for no individual or an organization can function well in the present technological dispensation without relevant knowledge in ICT. According to the research, very few tutors who have little idea about the use of computer technology do not have the confidence to apply their knowledge to the profession. They lack personal motivation hence find it impossible integrating technology in music education. Lack of confidence may come as a result of lack of frequent use of technological facilities. It is therefore recommended that distributions of computer technology in the colleges should embrace departmental focus instead of the centralized system (laboratory system) to enhance easy access and use by the tutors. Finally, as advocated by both tutors and students, it is recommended that computer music technology be introduced into the current music curriculum in the colleges of education to enhance music teaching in areas like Aurals, Composition and Piano skills teaching which they find difficult.

\section{Suggestion for further studies}

The study was a survey and limited to the Colleges of Education in the Volta Region and addressed one area in education. It is therefore suggested that in-depth study could be done into how the use of technology enhances academic improvement in music among colleges of education as a whole. Again, there could be a comparative study of two or more schools in relation to academic performance in music and usage of computer technologies by teachers during instructional hours. It is hoped that, this research will spread across all other educational institutions that benefit from ICT integration process and the teaching of music as a subject to prepare us meet global digital quest.

Acknowledgement: Augustine Adjei Mrs, Mrs. Missper Mawusi, Sesakor Joy Mawusi, Dela Ernest Mawusi, Aseyi Mawusi Yvonne and Elikem Kingsley Mawusi

\section{References}

[1] Akuno, E. A. \& Digolo B. (2000). Computer as A strategy for Enhancing Music Education in Kenyan Institutions of Higher Learning. A paper presented at the National Conference on Higher Education for Human Development in Kenya, Kenyatta University, 17th - 20th April

[2] Allen, J. (2004) Discrimination of modes of action of antifungal substances by use of metabolic footprinting. Appl Environ Microbiol 70(10), 6157-65

[3] Amedahe, F. K. (2002). Fundamentals of educational research methods. Mimeograph. Cape Coast, University of Cape Coast Press.

[4] Anderson, J. R., Reder, L. M., \& Simon, H. A. (1996). Situated learning and education. Educational Researcher, 25(4), 5-11.

[5] Bajjaly, S.T., 1998. Strategic information systems planning in the public sector. Am. Rev. Public Admin., 28, 75-85.

[6] Barron, A. (1998). Designing Web-based training. British Journal of Educational Technology, 29(4), 355-371.

[7] Bauer, W. I., Reese, S. \& McAllister, P. A.(2003). Transforming music teaching via technology: The role of professional development, Journal of Research in Music Education, Winter 51(4), 289-301.

[8] Berge, Z. (1998). Guiding principles in Web-based instructional design. Education Media International, 35(2), 72- 76.

[9] Black, J. B., \& McClintock, R. O. (1995). An interpretation construction approach to constructivist design. Retrieved May 6, 2017,

from http://www.ilt.columbia.edu/publications/papers/ICON_print.html

(http://en.unesco.org/themes/ict-education), 
[10] Brennan, S. E., \& Lockridge, C. B. (2006). Computer-mediated communication: A cognitive science approach. ELL2, Encyclopedia of Language and Linguistics,, pp. 775-780.

[11] Brown, J., Collins, A., \& Duguid, P. (1989). Situated cognition and the culture of learning. Educational Researcher, 18 (1), 32-42.

[12] Brush, T., \& Saye, J. (2000). Implementation and evaluation of a student- centered learning unit: A case study. Educational Technology Research \& Development, 48(3), 79-100

[13] Carlson, S., and C.T. Gadio. (2002). Teacher professional development in the use of technology. In W.D. Haddad and A. Draxler (Eds), Technologies for education: Potentials, parameters, and prospects. Paris and Washington, DC: UNESCO and the Academy for Educational Development. • Tinio, V. ICT in Education.

[14] Clark, C., \& Munn, R. E.(1986. ). Sustainable development of the biosphere, Cambridge University Press. Quarterly Journal of the Royal Meteorological Society, 114, 480.

[15] Clark, C. M., \& Peterson, P. L. (1986). Teachers' thought processes, in:M. C. Witt rock (Ed.)Handbook of research on teaching (New York, Macmillan).

[16] Coombs, R., \& Hull, R. (1996). Knowledge management practices' and path-dependency in innovation. Research Policy, 27(3), 237-253

[17] Creswell, J. W. (2003). Research design: Qualitative, quantitative, and mixed methods approaches $\left(2^{\text {nd }}\right.$ ed). Thousand Oaks, C.A: Sage.

[18] Dufner, D. (2002). Can Private Sector Strategic Information Systems Planning Techniques Work for the Public Sector? Communications of the Association for Information Systems: 8, (28). Retrieved (October 1, 2017) from http://aisel.aisnet.org/cais/vol8/iss1/28/

[19] Duffy, T. M. \& Cunningham, D. J. (1996). Constructivism: Implications for the design and delivery of instruction. In D. H. Jonassen (Ed.), Educational communications and technology (pp. 170-199). New York: Simon \& Schuster Macmillan

[20] Ely, D. P. (1993). Computers in schools and universities in the United States of America. Educational Technology, 33(9), 53-57.

[21] Ezell, M. J., \& O'Keeffe, K. O. (1994). Cultural artifacts and the production of meaning: The page, the image, and the body. Ann Arbor, MI: University of Michigan Press. Retrieved (October 4, 2017) from https://www.researchgate.net/publication/255583024_Constructing_on_Constructivism_The Role of Technology

[22] Fang, Z. (1996). A review of research on teacher beliefs and practices. Educational Research, 38(1), 47-65

[23] Flolu, J. E. (1994). Re-Tuning Music Education in Ghana: A Study of Cultural Influences and Musical Developments, and of the Dilemma Confronting Ghanaian School Music Teacher. University of York: Department of Music, pp. 57

[24] Fountain, J. E. (2001), The Virtual State: Transforming American Government? Nat Civic Rev, 90: 241-252. doi:10.1002/ncr.90305

[25] Gardner, H. (1991). Frames of mind. New York: Basic Books.

[26] Government of Ghana (2000). Ghana Education Trust Fund Act, (p. 1-8)

[27] Government of Ghana (2005). Government of Ghana Ministerial ICT Policy Statement: Accra: NBS Multimedia

[28] Government of Ghana (2015). Ghana ICT in Education Policy, 6-37

[29] Honey, M., Culp, K. M., \& Carrigg, F. (2000). Perspectives on technology and education research: Lessons from the past and present. Educational Computing Research, 23 (1), 5-14.

[30] Iowa Research Online, (1981). Descriptive Survey. Marilyn Zurmuehlin Working Papers in Art Education1, 54-63. Retrieved (October 10, 2017) from http://ir.uiowa.edu/mzwp/vol1/iss1/12

[31] Jonassen, D. \& Reeves, T. (1996). Learning with technology: Using computers as cognitive tools. In D. Jonassen (Ed.), Handbook of Research Educational on Educational Communications and Technology, 693-719. New York: Macmillan.

[32] Jonassen, D. H. (1991). Evaluating constructive learning: Educational Technology, 31 (9), pp. 28-33. 154 
[33] Jonassen, D. H., Peck, K. L., and Wilson, B. G. (1999). Learning with technology: A constructivist perspective. New York: Prentice Hall.

[34] Kennedy, D. M., \& McNaught, C. (1997). Design elements for interactive multimedia. Australian Journal of Educational Technology, 13(1), 1-22.

[35] Lave, J. (1988). Cognition in practice: Mind, mathematics, and culture in everyday life. Cambridge, England: Cambridge University Press

[36] Lebow, D. (1993). Constructivist values for instructional systems design: Five principles toward a new mindset. Educational Technology, Research and Development, 41(3), 4-16.

[37] Lehman,P.R. (2001). The class of 2001: Coping with the computer bandwagon. Reston, VA: a paper presented at the Music Educators National Conference.

[38] Malachi D. (2007), A survey of computer usage in Secondary School. Nairobi Kenya; Unpublished thesis

[39] Mangesi, K, (2007), ICT in Education in Ghana; Survey of ICT and Education in Africa: Ghana Country Report, 1-9

[40] Marcellino, R. (1996). Technology and Music Literacy. Journal of the Australian Music Centre,14 (47), 45-48

[41] Means, B. 1994. Introduction: Using technology to advance educational goals. The reality behind the promise. San Francisco: Jossey-Bass (pp. 1-21).

[42] Medlin, B.D. (2001). The factors that may influence a faculty member's decision to adopt electronic technologies in instruction (Doctoral dissertation, Virginia Polytechnic Institute and State University, 2001). ProQuest Digital Dissertations. (UMI No. AAT 3095210).

[43] Mereku C.W.K. (1999). Challenges in implementing the new music and dance syllabuses for primary and junior secondary schools in Ghana. Paper Presented at the Workshop on Teaching of African Music and Dance: University of Ghana, Legon: International Centre of African Music and Dance (ICAMD). 15 $5^{\text {, }}-17^{\text {th }}$ December, 1999.

[44] Mfum-Mensah, O. (2003). Computers in Ghanaian Secondary Schools: Where Does Equality Come In?. Unpublished Ph.D. dissertation. University of Toronto.

[45] Miller, D. C. (2000). EEG Studies with Young Children: Music educators can benefit from knowing what has been learned about young children via the electroencephalogram (EEG). Music Educators Journal, 87(2), 28-54.

[46] Monahan, T. (2004). Technology policy as a stealth agent of global change: Globalisation. Societies and Education, 2, 355-376

[47] Mooij, T., \& Smeets, E. (2001). Modeling and supporting ICT implementation in secondary schools. Computers \& Education, 36, 265-281

[48] Moore, M. G., \& Kearsley, G. (1996). Distance education: A systems approach. Boston, MA: Wadsworth.

[49] Muro, D. (1996). On behalf of Humanity in the technological edge. The World \& I, 301-313.

[50] Myhre, O. R. (1998). I think this will keep them busy: computers in a teacher'sthought and practice. Journal of Technology and Teacher Education, 6(2/3), 103.

[51] Nketia, J. H. (1966). Music Education in African Schools: A Review of the Position in Ghana. in International Seminar on Teacher Education in Music. Ann Arbor: Univ.of Michigan, (pp. 231-243)

[52] Norris, D., McQueen, J. M., \& Cutler, A. (2003). "Perceptual learning in speech," Cognitive. Psychology, 47, 204-238.

[53] Nyamful, A.Y. (2016). The Current State of Music Education in Ghana: A call for integration of Information and Communication Technology (ICT). Journal of Arts and Humanities, 5, (4), 62-68. Retried (October 4, 2017) from http://www.theartsjournal.org/index.php/site/article/view/716. doi:http://dx.doi.org/10.18533/journal.v5i4.716.

[54] Ohene-Okantah, M. (1997). Music in Ghanaian Education: In Search of a National Philosophy. $21^{\text {st }}$ Annual National Conference of Ghana Music Teachers' Association, Akropong-Akwapim, $25^{\text {th }}-28^{\text {th }}$ August, 1997. Retrieved (October 1, 2017), from www.scientificafrican.org/sciafr/publications/musiceducator/no10/.../at_download

(pp. 3-4)

[55] Okonkwo, V. N. (2008). ICT and Music Education: The New Path Music Enthusiast in the Nigerian Society. Journal of Women in Colleges of Education (JOWICE) 10 (1), 36-38. 
[56] Oliver, R. (2000). Creating Meaningful Contexts for Learning in Web-based Settings. Proceedings of Open Learning 2000, 53-62. Brisbane: Learning Network, Queensland

[57] Oliver, R. \& Towers, S. (2000). Benchmarking ICT literacy in tertiary learning settings. In R. Sims, M. O'Reilly \& S. Sawkins (Eds). Learning to choose: Choosing to learn. Proceedings of the 17th Annual ASCILITE Conference, 381-390. Lismore, NSW: Southern Cross University Press.

[58] Ottesen, E. (2006). Learning to teach with technology: authoring practised identities. Technology. Pedagogy and Education, 15(3), 275-290. doi:10.1080/14759390600923568

[59] Pajares, M. (1992). Teacher's beliefs and educational research: cleaning up a messy construct. Review of Educational Research, 62(3), 307-332

[60] Parisot, A.H. (1997). Distance education as a catalyst for changing teaching in the community college: Implications for institutional policy. New Directions for Community Colleges, 99, 5-13.

[61] Pelgrum, W. J. (2001). Obstacles to the integration of ICT in education: Results from a worldwide educational assessment. Computers \& Education, 37, 163-178.

[62] Peters, G. D. (2000). Music Software and Emerging Technology. Music educators Journal, 79(3), 2225.

[63] United Nations (2003). Population, Education and Development: The Concise Report, New York.

[64] Reeves, T.C. \& Janassen, D.H. (1996). Learning With Technology: Using Computers As Cognitive Tools. AECT: 1800 North Stonelake Drive, Suite 2 Bloomington, IN 47404

[65] Reiser, R. A. (2002). Instructional planning: A guide for teachers (2nd Ed.), Boston: Allyn \& Bacon.

[66] Republic of Ghana (2003). The Ghana ICT for accelerated development (ICT4AD) policy. Accra, Ghana: Graphic Communications Group Limited. Retrieved (February 15, 2008) from http://www.moc.gov.gh/moc/PDFs/Ghana_ICT4AD_Policy.pdf

[67] Razavieh, A. (1990). Introduction to research in education (4th ed.). Fort Worth: Harcourt Brace Jovanovich.

[68] Richards, R. T. (1998). Infusing technology and literacy into the undergraduate teacher education curriculum through the us of electronic portfolios. T.H.E. Journal, 25(9), 46-50.

[69] Rogers, E.M. (1962). Diffusion of Innovations. New York; Free Press.

[70] Rogers, E.M. (2003). Diffusion of innovations (5th ed.). New York: Free Press.

[71] Rudolph,T. E. (2004) (Teaching Music with Technology ( $2^{\text {nd }}$ ed), GIA Publications, Inc. Chicago

[72] Sevan, N. (2016). Music Software in the Technology Integrated Music Education. Bartin University, Faculty of Education, Department of Fine Arts, Turkey. Turkish Online Journal of Educational Technology (2016). 15(2), 78, Retrieved (October 2, 2017) from sevannart@bartin. edu.tr

[73] Schware, R. \& Dean A. (2003). Deploying e-government programs: the strategic importance of 'I' before 'E'”, info, 5, (4), 10-19.

[74] Schwarz, N. (1999). Reports of subjective well-being: Judgement process and their methodological implications. In Kalneman, D., Diener, \& Schwarz (Eds.), Well-being: The foundations of hedomic psychology (pp. 61-84). New York: Russell Sage Foundation.

[75] Soloway, E. \& Pryor, A. (1996). The next generation in human-computer interaction. Communications of the ACM, 39(4), 6-18.

[76] Surry, D., \& Farquhar, J. (1994). Adoption analysis: An additional tool for instructional developers. Education and Training Technology International, 31(1), 19-23.

[77] Taylor, R. (1980). The Computer in the School: Tutor, Tool, Tutee. New York, NY: Teachers College Press.

[78] UNESCO. (2001). Teacher Education through Distance Learning: Technology - Curriculum - Cost Evaluation Paris: UNESCO

[79] United Nations (2003). Report on Population, Education and Development. United Nations Publication, New York.

[80] Watson, D. M. (1998). Blame the technocentric artifact! What research tells us about problems inhibiting teacher use of IT. In G. Marshall, \& M. Ruohonen (Eds.), Capacity building for IT in education in developing countries (pp. 185-192). London: Chapman \& Hall.

[81] Yildirim, S. (2007). Current Utilization of ICT in Turkish Basic Education Schools: A Review of Teacher's ICT Use and Barriers to Integration. International Journal of Instructional Media, 34, (2), 171-86 
[82] Yamaha Corporation (1994). Facts about Technology Users. New Ways in Music Education. Grand Rapids, MI: America.

[83] Young, J. (2002). The 24-hour professor. The Chronicle of Higher Education, 48(38), 31-33

[84] Zeichner, K. M., Tabachnick, B. R. \& Densmore, K. (1987). Individual instructional and cultural influences on the development of teachers' craft knowledge, in: J. Calderhead (Ed.). Exploring teachers' thinking (Eastbourne, Cassell) 